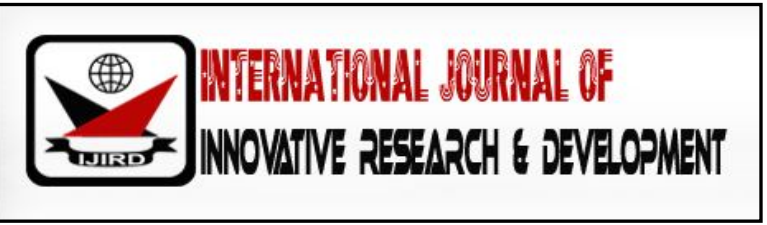

ISSN 2278 - 0211 (Online)

\title{
Influence of Business Process Reengineering on Electronic Commerce Strategy as Adopted by Commercial Banks in Kenya
}

Caleb Odhiambo Onjure
PhD Student, Jomo Kenyatta University of Science and Agriculture and Technology
College of Human Resource Development, Nakuru, Kenya
Daniel M. Wanyoike
PhD Lecturer, Jomo Kenyatta University of Science and Agriculture and Technology
College of Human Resource Development, Nakuru, Kenya
Joseph Mungatu
PhD Lecturer, Jomo Kenyatta University of Science and Agriculture and Technology
Department of Statistics and Actuarial Science, Nakuru, Kenya

\begin{abstract}
:
The ease of doing business in Kenya remains weak, and the rapid development of information and technology is shaking the foundation of banking industry. The cut throat competitive pressure has led to survival challenges of many banks. Business Process Reengineering is therefore management approach to create change through process improvements by reducing production/ service cost, improving quality and customer service. The banking operations and functions intended to meet the challenges of bank consolidation, minimizing operating cost, outsourcing, portfolio investment, payments and settlement system call for innovative banking practices through Business Process Re-engineering. The main objective of this study was to analyze the influence of Business Process Reengineering on e-commerce strategy as adopted by commercial banks in Kenya. The general objective was operationalized by in-depth study of the following constructs: business analysis and information management, process excellence, project management. The study employed a descriptive survey research design. Selfadministered questionnaire was distributed to management, supervisors, clerical and secretariat, and support staff randomly selected from the commercial banks that are sample respondent. The target population was 36,923, and the sample size of 384. The scope of the study targets was 43 commercial banks in Kenya. The quantitative data was analyzed by the use of statistical package for social scientists (SPSS). Result from the research findings indicates that business process reengineering influences electronic commerce strategy adoption by commercial banks in Kenya in different directions and magnitude: Business analysis by -0.006 , process excellence by 0.173 and project management by 0.108 . Process excellence has a positive and significant relationship with Electronic Commerce strategy as adopted by commercial banks in Kenya. However, business analysis has a negative and insignificant impact on electronic commerce strategy as adopted by commercial banks in Kenya. The study recommends that the banks should change their strategic approach to Business Analysis, so that a positive impact on electronic commerce strategy could be achieved. The study further recommends for improved effective project management of our commercial banks. The study also recommends for improvement in all process excellence approaches. Future studies should consider exploring other non-commercial banks so as to support the generalization of the findings. Future studies can also focus on the influence of other organizational capabilities.
\end{abstract}

Keywords: Business process reengineering, business analysis, process excellence, project management

\section{Introduction}

This research studies the influence of Business Process Reengineering (BPR) on electronic commerce strategy as adopted by commercial banks in Kenya. Business Processes represent a core of the functioning of an organization because the company primarily consists of processes, not products or services. The goal of business process reengineering is to redesign and change the existing business practices or process to achieve dramatic improvement in organizational performance. 


\subsection{Background Statement}

One of the constants in most organizations today is change (Martin \& Huq, 2006). The $21^{\text {st }}$ century global trend in business and industry is experiencing rapid changes. The worldwide commerce system is evolving from traditional activities to knowledge and information based economy (Ghobakhloo, Amada \& Airanda, 2012). According to Otuya et al. (2014), the corporate organizations especially the banking industry worldwide has been characterized by fundamental changes taking place in the business environment. Business activities have taken a different turn as the general consumers become more complex. Their purchase behavior is becoming more and more complex and highly unpredictable. As reported by Chartered Institute of Management Accounts (CIMA, 2010), banks target mass-affluent consumers, who want to feel special; do not want to wait in a queue like everyone else; who feel they have worked hard for their money and they expect to be treated well. People in that market seek good service above all else, so they expect to get what they pay for or they will make their feelings clear (Ramosedi, 2010).

The Sub-Saharan African States (SSA's) financial sector continues to be less developed even when compared to other emerging market regions. According to KPMG, (2015), the development of the SSA banking sector is still to an extent constrained by the small size of national markets. In many cases, this prevents banks operating in their home country from realizing the benefits of economies of scale. Increased regional economic and financial integration represents an opportunity to overcome this obstacle. The region has witnessed a rapid expansion of pan-African banking groups in recent years, and as domestic markets become saturated, banks are often forced to look beyond borders for potential growth opportunities. Secondly, regulatory changes in the country where banks are domiciled could also influence ambitions to expand beyond borders (KPMG, 2015).

Banks should position themselves strategically so that they can be able to provide these important services to the customer and sustain a competitive advantage over the competitors who provide the same services that banks are providing to survive in the current competitive, local and global challenging environment. The strategic positioning needs creative thinking and experimentation with new business models and the ability to recognize what form of restructuring is needed. These banks have to position themselves strategically to remain on course as well as to achieve their vision and mission and to sustain a competitive advantage over the competitors, hence the need to modernize equipment, adopt the latest I.T, develop human resource, continuously improve management styles, create efficient and low cost innovative services and to provide services that are differentiated from the competitors other than the usual services so as to attain customer loyalty (KPMG, 2015).

\subsection{Statement of the Problem}

In the recent past there has been witnessed turbulent times in the banking industry in Kenya. On 14th August, 2015, Central bank of Kenya (CBK) announced it has appointed the Kenya Deposit Insurance Corporation (KDIC) as a receiver in the interest of (Dubai Bank's) depositors, creditors and members of the public. In October 2015, the Central Bank of Kenya (CBK) put another Kenyan bank-Imperial Bank, under statutory management, barely months after taking similar measures against Dubai Bank. In April 2016 Chase bank placed under receivership (the third bank to be placed under the CBK in the past YEAR). In September 2016, Ecobank selling its office tower to recoup losses accrued from banking business. This is a problem that is causing major concerns in the financial sector. Now more than ever, banking institutions have to optimize their processes, control their cost structure, and explore new operating models using all the tools at their disposal. Business Process Reengineering is critical for superior firm performance in electronic commerce (e-commerce), and plays important role in successful Customer Relationship Management implementation. The goal of business process reengineering is to redesign and change the existing business practices or process to achieve dramatic improvement in organizational performance. The banking operations and functions were redesigned to meet emerging challenges of bank consolidation, slashing operating cost, outsourcing, portfolio investment, payments and settlement systems. However, empirical studies have seldom addressed aspects of business process reengineering (such as business analysis and information management, process excellence, and project management) influence on e-commerce strategy as adopted by commercial banks in Kenya. Therefore, this study intends to focus on the influence of Business Processes Reengineering on e-commerce strategy as adopted by commercial banks in Kenya in response to the competitive environment.

\subsection{General Objective}

To determine the Influence of Business Process Reengineering on e-commerce Strategy as Adopted by Commercial Banks in Kenya

\subsection{Specific Objective}

- To determine the influence of business analysis on e-commerce strategy as adopted by commercial banks in Kenya

- To establish the influence of process excellence on e-commerce strategy as adopted by commercial banks in Kenya

- To ascertain the influence of project management on e-commerce strategy as adopted by commercial banks in Kenya 


\subsection{Research Hypotheses}

- $\mathrm{H}_{0}$ : There is no significant influence of business analysis on e-commerce strategy as adopted by commercial banks in Kenya

- $\mathrm{H}_{0}$ : There if no significant influence of process excellence on e-commerce strategy as adopted by commercial banks in Kenya

- $\mathrm{H}_{0}$ : There is no significant influence of project management on e-commerce strategy as adopted by commercial banks in Kenya

\subsection{Justification of the Study}

The banking sector has shown tremendous growth with commercial banks not left behind. This line of research has theoretical value, as it aids researchers in developing and validating general applied frameworks aimed at facilitating the utilization of BPR to attain expected electronic commerce strategy adoption hence strategic advantage. The findings of this study act as a guide to management of commercial banks in their steps to developing sustainable competitive advantage and commitment to organization's strategy. It also assists policy makers in developing policies which would evaluate the impact of BPR on electronic commerce strategy in the banking sector hence developing policies which regulate and support the development of e-commerce strategy in banks. To the Government of Kenya this research is important in policy formulation for orderly economic growth. The research finding also extends knowledge in the world of academics in the same area of Strategic Management; it is useful as literature in the area of e-commerce strategy in the banking industry.

\subsection{Scope of the Study}

Only the commercial banks in Kenya were considered. The research was carried out in all commercial bank headquarters in Nairobi. The budget for this project was Ksh. 398,044.00. The research was carried out between July, 2015 and July, 2017. The independent variables in the study will be business analysis, Process Excellence, and Project Management. The dependent variable was electronic commerce strategy as adopted by commercial banks in Kenya.

\subsection{Limitations of the Study}

The challenges encountered during the study include financial challenges given the rising cost of materials in Kenya today and transportation. Furthermore, the subject of the study is sensitive and making appointment with some respondents caused some delays. However, the researcher used the focused groups effectively for better results.

\section{Literature Review}

The study was guided by Innovation Diffusion Theory and Resource Based View theory.

\subsection{Conceptual Framework}

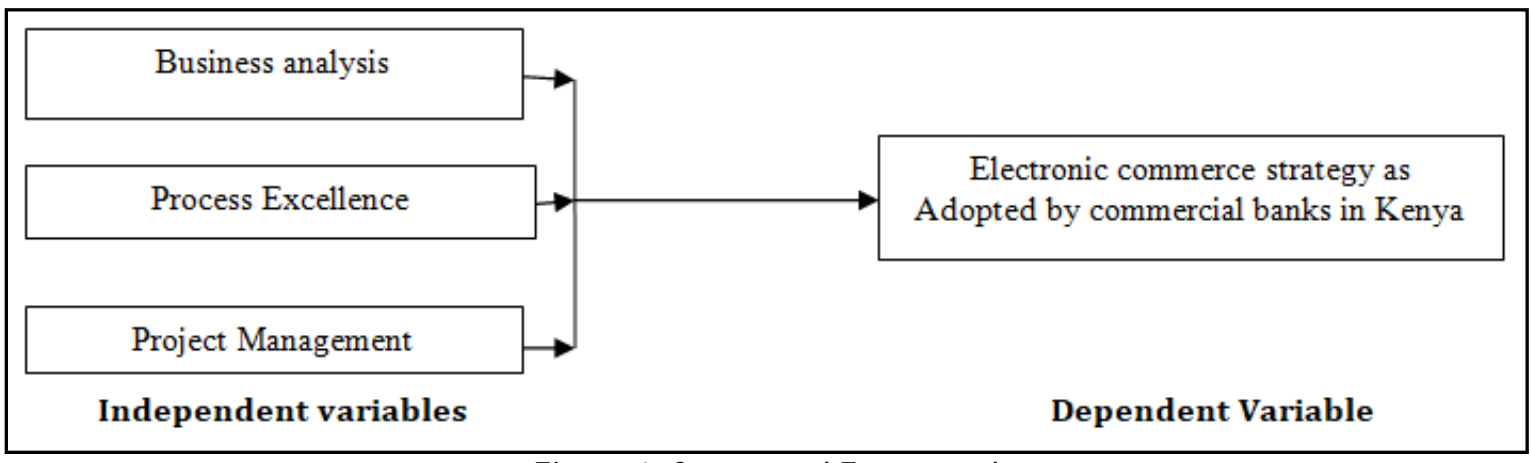

Figure 1: Conceptual Framework

\section{Research Methodology}

\subsection{Research Design}

Chandran (2004) describes research design as an understanding of conditions for the collection and analysis of data in a way that combines their relationships with the research to the economy of procedure. The research design, deal with the detailing of procedures that will be adopted to carry out the research study (Harper \& Marcus, 2003). The study employed a descriptive survey research design. This is because; it permits the collection of data through questionnaires administered to a sample quickly, efficiently, and accurately (Osoo \& Onen, 2007). It is an efficient method for systematically collecting data from broad spectrum of individuals and educational settings (Kothari, 2004). The study sought to describe the identified variables as they are without manipulation of variables. The major purpose of descriptive research is a description of the state of affairs, as it exists without manipulation of variables (Kombo \& Tromp, 2006). 


\subsection{Target Population}

A population is defined as a complete set of individuals, cases or objects with some common observable characteristics (Mugenda \& Mugenda, 2003). Duncombe (2007) defines a population frame as "an objective list of the population from which the researcher can make his or her selection." A population frame must thus contain an up-to-date list of all those that comprise the target population. The target population of this study was 36,923, and comprised of the employees of all commercial banks, based at their headquarters in Nairobi.

\begin{tabular}{|c|c|}
\hline Cadre of staff & Target number \\
\hline Management & 9,584 \\
\hline Supervisory & 6,464 \\
\hline Clerical and Secretariat & 18,539 \\
\hline Support Staff & 2,336 \\
\hline Total & $\mathbf{3 6 , 9 2 3}$ \\
\hline
\end{tabular}

Table 1: Target Population

Source: Bank Supervisory Annual Report by CBK (2015)

\subsection{Sample Procedure and Sample Size}

Sampling design refers to a research plan that indicates how cases are to be selected for observation or as respondents (Mugenda \& Mugenda, 2003). Any statements made about the sample should also be true of the population (Orodho, 2003). The target population was divided into strata according to cadre of staff, thereafter sample size determined by applying (Cooper \& Schindler, 2003) formula. Simple random method was used to distribute the questionnaires.

$\mathrm{n}=\mathrm{z}^{2} \mathrm{pq} /\left(\mathrm{d}^{2}\right)$

Where: $\mathrm{n}=$ desired sample size, $\mathrm{z}=$ standard normal deviation at the required confidence level, $\mathrm{p}=$ proportion in the target population estimated to have the characteristics being measured, $q=1-p, d=l e v e l$ of statistical significance set.

At $95 \%$ level of confidence and $\mathrm{P}=0.5$, the $\mathrm{z}$ statistics is 1.96 . The sample size $=\mathrm{n}=\left((1.96)^{2}(.5)(.5)\right) /(.05)^{2}=384$. This sample size is considered representative and comprehensive in the coverage of the study objectives and economical in terms of time and money.

\begin{tabular}{|c|c|c|}
\hline Cadre of staff & Target number & Sample Size \\
\hline Management & 9,584 & 100 \\
\hline Supervisory & 6,464 & 67 \\
\hline Clerical and Secretariat & 18,539 & 193 \\
\hline Support Staff & 2,336 & 24 \\
\hline Total & $\mathbf{3 6 , 9 2 3}$ & $\mathbf{3 8 4}$ \\
\hline
\end{tabular}

Table 2: Sample Size

\subsection{Data Collection Procedure}

On appropriate date, the researcher administered the questionnaire to the respondents on agreement with the respondent. There was an introductory note to let the respondent to feel free to participate. Questions that were not clear to the respondent were clarified. The questionnaires were administered by the researcher. The researcher ensured that the questionnaires are received at the right time and that everything is clarified clearly to the respondents before they responded to the items in the questionnaire. The researcher also liaised with the relevant authorities to allow the study to be carried out and similarly, to conduct a pilot study to familiarize with the respondents. Similarly, the research got authority from NACOSTI, County Directors of Education and County Commissioners for Nairobi and Nakuru counties.

A period of one month was given to the respondents to answer the questions postpaid envelops with researchers' postal address was left so that once the questionnaire is filled they will be posted. Contact mobile number and e-mail address of the researcher was given to the respondent. Researchers such as Herindranath et al (2008), Tan et al (2009) and Wanyoike (2013) have used similar data collection procedures in similar studies.

\subsubsection{Research Instruments}

Questionnaire and interview guide were the research instruments. Questionnaires, incorporating both open-ended and closed-ended questions items were used to gather the study's data. According to Cooper and Emory (2008), the questionnaire is conveniently used because it is cheaper and quicker to administer, it is above researcher's effect and variability, and is highly convenient for the respondents as they could fill them during free times or when workloads are manageable. The instruments incorporated Likert scales to measure perception, attitude, values and behavior. According to Mugenda \& Mugenda (2003), the questionnaire allows the researcher to collect information from a large sample with diverse background; the findings remain confidential, save time and since they are presented in paper format there is no opportunity for bias. The data received from questionnaires is appropriate and can easily be arranged and analyzed. Self-administered 
questionnaire is the only way to elicit self-reports on people's opinion, attitudes, beliefs and values (Sproul, 1998 as quoted by Kasiva, 2012). Questionnaires were distributed to management supervisory staff, clerical and secretarial staff and support staff. Likert (1932) scale was used to determine if the respondent agreed or disagreed in a statement. They are also easy to administer because each item is followed by an alternative answer and is economical. Interview guide were administered by the researcher to access key information to be utilized in conclusion. It was administered to management.

\subsubsection{Reliability of Instrument}

This refers to the extent to which data collection techniques and analysis will yield similar findings by other observers. The measurement of reliability provides consistency in the measurement of variables. Internal consistency reliability is the most commonly used psychometric measure for assessing survey instrument and scales (Zhang, Waszink \& Wijngaard, 2000). Cronbach alpha $(\alpha)$ is the basic formula for determining the reliability based on internal consistency (Kim \& Cha, 2002). The standard minimum value of alpha $(\alpha)$ is 0.7 recommended by Malhotra (2004). Construct used in this study was tested for internal consistency reliability where values greater than 0.7 indicated presence of a strong internal consistency in the measurement. Table 3 produced a Cronbach alpha $(\alpha)$ values greater than 0.7, indicating that the questionnaire is reliable as recommended by Fraenkel \& Wallen (2000) quoted by Otiso and Simyu (2017).

\begin{tabular}{|c|c|c|}
\hline Study Variable & Number of Test & Cronbach Alpha \\
\hline Business Analysis & 15 & 0.9542 \\
\hline Process Excellence & 15 & 0.9516 \\
\hline Project Management & 15 & 0.9550 \\
\hline
\end{tabular}

Table 3: Reliability Test

\section{Results and Discussion}

\subsection{Response Rate}

Out of 385 questionnaires that were distributed to potential respondents, 244 were duly filled and returned to the researcher. This translates to a response rate of $63.38 \%$. Response rate refers to the number of questionnaires returned divided by the sample size and the result multiplied by one hundred (Baruch and Holtom, 2008). The response rate results were tabulated as presented in Table 4.

\begin{tabular}{|c|c|c|}
\hline Questionnaires & Frequency & Percentage \\
\hline Returned & 244 & 63.54 \\
\hline Unreturned & 140 & 36.46 \\
\hline Total & $\mathbf{3 8 4}$ & $\mathbf{1 0 0}$ \\
\hline
\end{tabular}

Table 4: Response Rate

The response rate of $63.54 \%$ was found to be sufficiently adequate for analysis and for discussions of the study findings when compared to other research results by Muturi (2014)-62\%, Ngumi (2013)-62\%, Wanyoike et al. (2013)-56\%, Alam and Noor (2009) - 48.25\%, Mutula and Brakel (2007) - 34.5\%, Chiware and Dick (2008) - 58.29\%. The unreturned questionnaire (38.44\%) could be attributed to delay on the part of the respondent completing and hence being unable to return by on time. According to Mugenda and Mugenda (2003), for generalization purposes, a response rate of $50 \%$ is adequate, while $60 \%$ is good and a response of $75 \%$ is excellent. Hager, Wilson, Pollack and Rooney (2003) recommended $50 \%$. Most importantly, the overall response rate of $63.38 \%$ is higher than the average response rate of $30 \%$ for survey research recommended by Saunder and Lewis (2009) and Sekara (2003).

\subsection{Demographic Characteristics of the Sample}

The profile of respondents identifies the main information about the characteristics of those who participated in the research process depending on the relevance of the information sought. The researcher sought to find out the distribution of the respondents according to gender, age bracket, and education level. The aim was to deduce any trend from the respondent's profile that was directly linked to the variables of the study. Similarly, previous studies have noted some relationship between these demographics factors and ecommerce strategy adoption (Looi, 2004). According to Sifer, Puddy, Warren and Robert (2002), the analysis of demographic characteristics traits of the sample helps the researcher and research consumer to make conclusion regarding the representativeness of the sample, and consequently, the generalization of the collected data.

\subsubsection{Gender of the Respondents}

The study sought to establish gender of the respondents so as to establish on the criteria used by the management in employing employees on gender consideration. Gender is a cross-cutting issue within the development policies of most 
international donors and national governments. If gender impacts are not evaluated, they are unlikely to be given any attention (World Bank Publication, 2010). The results were tabulated as indicated in Table 5.

\begin{tabular}{|c|c|c|}
\hline Gender & Frequency & Percentage \\
\hline Male & 143 & 58.61 \\
\hline Female & 101 & 41.39 \\
\hline Total & $\mathbf{2 4 4}$ & $\mathbf{1 0 0}$ \\
\hline
\end{tabular}

Table 5: Distribution of Respondents by their Gender

The findings show that $58.61 \%$ of the respondents are male and $41.39 \%$ female employees. This implies that there is a relative effort towards achieving gender equality in the commercial banks in Kenya since the difference between male and female counterpart is growing minimal, however there is still a big gap. This was also reflected in the interviews held with selected managers in the commercial banks in Kenya. The finding is consistent with the result by Wachudi and Mboya (2009) that demonstrated that boards of commercial banks in Kenya are male-dominated- on average, out of a typical board size of 8 members, only 1 is a female director. Gakure (2001) also observed male dominance in formal and informal sector.

The study further established that few women on the board may have come about because may be women in general do not have the necessary training and experience to work in the financial sector. That board gender diversity has no significant effect on the performance of banks, and that female employees face glass ceiling (that is promotion to a certain level but not beyond) in those organizations (Williams 1992); and that women are tokens in the banking industry giving a hand to the tokenism theory. Similar study by Majid, Yusuff and Raza (2015) also found that women are under-represented in the skilled workforce of the Malaysian construction industry. The findings by Ngugi (2016) further revealed that women constitute 48 per cent of Barclay's 2,762 employees, 43 per cent of Co-op's 3,948 and 42 per cent of KCB's 6,082 permanent workers. The findings by Masanja (2010) also established that there was low women participation in science, education and employment in Africa. The Kenya Gender Analysis Report (2017) further indicated that men control access to most productive assets in Kenya.

\subsubsection{Age of the Participants}

The researcher found it paramount to establish the age bracket of the respondent. This is a demographic feature that affects behaviors or perception of an individual on issues in organizations. The results were tabulated as indicated in Table 6 .

\begin{tabular}{|c|c|c|c|}
\hline \multicolumn{2}{|c|}{ Age Group } & Frequency & Percent \\
\hline & 60 and above years & 1 & .4 \\
\hline & $50-59$ years & 10 & 4.1 \\
\hline & $40-49$ years & 51 & 20.9 \\
\hline & 30-39 years & 64 & 26.2 \\
\hline & Below 30 years & 118 & 48.4 \\
\hline & Total & $\mathbf{2 4 4}$ & $\mathbf{1 0 0 . 0}$ \\
\hline
\end{tabular}

Table 6: Distribution of Age Group

The finding established that $48.4 \%$ of the respondents are below 30 years, $26.2 \%$ of them are between $30-39$ years, $20.9 \%$ of them are aged between $40-49$ years, and $4.1 \%$ are $50-59$ years, and $0.4 \%$ are 60 years and above. It was observed that the majority of the respondents were aged above 30 years and above (52\%). The rest fell below 30 years $(48 \%)$. The smallest number of respondents was fifty years and above (4.5\%), which is in agreement with Ngumi (2013) finding that many banks' workforce is mainly aged below fifty years due to the periodic employee realignments which normally witness exit of older employees through either voluntary exit or employer initiated early retirement. The findings also back Doherty and Ellis-chadwick (2003) set of analysis, which demonstrated that organizations are most likely to adopt the Internet for information provision, marketing and direct sales purposes if their typical customer (internal and external) is male, young and a member of the professional/ managerial classes; and that young, professional males are typically enthusiastic and competent users of information technologies.

\subsubsection{Education Level of the Respondents}

The study sought to establish the education level of the respondents. The respondents were asked to state their highest academic level. The level of education is a key factor when it comes to understanding and perception of issues in an organization. According to Murphy and Myors (2004) as quoted by Nyakoi (2016), education level determines the respondents' ability to comprehend the survey questions. The results were tabulated as indicated in Table 7. 


\begin{tabular}{|c|c|c|c|}
\hline \multicolumn{2}{|c|}{ Education Level } & Frequency & Percent \\
\hline & Primary Certificate & 1 & .4 \\
\hline & Secondary Certificate & 4 & 1.6 \\
\hline & College Diploma & 15 & 6.1 \\
\hline & University Degree & 224 & 91.8 \\
\hline & Total & $\mathbf{2 4 4}$ & $\mathbf{1 0 0 . 0}$ \\
\hline
\end{tabular}

Table 7: Distribution of Respondents by Highest Level of Education

The findings show that $0.4 \%$ of the respondent reached primary school as their highest level of education, $1.6 \%$ of the respondents have secondary level as their highest level of education, $6.1 \%$ of the respondents have college level as their highest level of education, $91.8 \%$ at university level. This shows that the respondents were capable and reliable to explore the underpinning issues related to the study. The role of education as a change agent is indisputable and has always been a central mechanism for transmission of skills and values for the sustenance of societies and promotion of social change (Lebaking \& Phalare, 2001). Employees need technical skills to apply skills and use techniques from education, training and experience, human professional experience is necessary to work effectively with the people and conceptualize and analyze complexities (Kimemia, 1990, as mentioned by Kathuku et al., 2017). According to the findings by Rahman, Rafiq and Momen (2009), high level of knowledge on enterprise management, influences offering of information that answers research question in a study.

\subsubsection{Respondents Area of Operation}

The study found it imperative to establish understanding on the area of operation of the respondents. This data was intended for the purpose of establishing on the respondent's awareness and level of understanding over the organizational strategies. The results were tabulated as indicated in Table 8.

\begin{tabular}{|c|c|c|c|}
\hline \multicolumn{2}{|c|}{ Respondents } & Frequency & Percent \\
\hline & Support staff & 20 & 8.2 \\
\hline & Clerical \& Secretariat & 92 & 37.7 \\
\hline & Supervisory & 36 & 14.8 \\
\hline & Management & 96 & 39.3 \\
\hline & Total & $\mathbf{2 4 4}$ & $\mathbf{1 0 0 . 0}$ \\
\hline
\end{tabular}

Table 8: Areas of Operation of Respondents

The findings show that management forms $38.5 \%$ of the respondent, supervisors forms $14.8 \%$, clerical and secretariat forms $37.7 \%$, and Support staff $8.2 \%$. This implies that the management formed the largest majority of respondents. However, with this kind of distribution, the researcher was satisfied that all areas were covered.

\subsubsection{Years of Work in the Bank}

The respondents were requested to indicate on how long they have worked in the organization, since this affects employee understanding on firm operations and processes; in this case the study assumed that the longer one has worked in the organization the more he or she understands the operations and processes in the organization. Experience also contributes to individual's competence on execution of organizational duties and roles on implementation of strategies. The finding of this enquiry is presented in Table 9.

\begin{tabular}{|c|c|c|}
\hline \multicolumn{1}{|c|}{ Year Worked in Bank } & Frequency & Percent \\
\hline Less than 2 years & 56 & 23.0 \\
\hline 2-3 years & 32 & 13.1 \\
\hline 4-5 years & 33 & 13.5 \\
\hline 5-6 years & 29 & 11.9 \\
\hline Over 6 years & 94 & 38.5 \\
\hline Total & $\mathbf{2 4 4}$ & $\mathbf{1 0 0 . 0}$ \\
\hline
\end{tabular}

Table 9: Years Worked in the Bank

The result from the findings indicates that the majority of employees in this company comprising $38.5 \%$ have worked for period more than six years, followed by $23 \%$ of the respondents who have worked for less than 2 years, while those who have worked for $2-3$ years constitute $13.1 \%$, those who have worked for $4-5$ years constitute $13.5 \%$. The minority of $11.9 \%$ 
have worked for 5-6 years. Study by Jelangat (2014) observed that majority of bank staffs have worked for less than 5 years (43.8\%); the finding attributed this to the rapid expansion of banking sector in the last decade resulting into a high number of employees engaged in the period. Ambani (2014) similarly observed that majority of staff in commercial banks are middle aged people who occupies management positions in their companies. This finding is an indication that the majority of the respondents have a reasonable experience with their organizations hence able to provide information based on their experience with the companies. Randoy et al. (2006) observed that one's experience depends on the number of years of service in the sector involved. (Afande, 2013) observed that it is assumed that the longer one worked in an organization, the more they understand the organization and hence the higher the ability to articulate issues pertaining to the organization. The respondent therefore is believed to understand the organization based on the period they have worked in the organization. Thus, implying that the more experienced a person is the more he understands the concept of corporate strategies and competitive advantage, principle, and policies of a given organization.

\subsection{Descriptive Analysis}

This section deals with specific information of the study with regard to specific objectives of the study. Descriptive Analysis focuses on describing and summarizing the basic feature of the data in a given study (Cooper \& Schindler, 2013). The descriptive statistics are used to summarize data regarding electronic commerce strategy adoption by Commercial Banks in Kenya. The responses spread within standard deviation statistical rule of $68 \%, 95 \%$ and $99.7 \%$ applies in all the interpretations in the rest of the document. This means that one responses spread within standard deviation has $68 \%$ of the data spread around the mean and 95\% for two standard deviations and 99.7\% for three standard deviations.

\subsubsection{Influence of Business Process Reengineering on Electronic Commerce Strategy Adoption by Commercial Banks in Kenya}

The main objective of the study was to determine the influence of Business Process Reengineering on electronic commerce strategy as adopted by commercial banks in Kenya. The objective was verified from respondent by use of Likert scaled statement on questionnaire.

\subsubsection{Whether the Organization Practices Business Process Reengineering}

The study sought to test whether the organizations identified with radical and new ways of carrying out her business operations, often enabled by new Information Technology capabilities to achieve critical contemporary measures of performance such as cost, service, quality, and speed. This was meant to establish whether commercial banks in Kenya practices Business Process Reengineering. The finding of this enquiry is as presented in Table 10.

\begin{tabular}{|c|c|c|c|}
\hline \multicolumn{2}{|c|}{ Response } & Frequency & Percent \\
\hline & YES & 238 & 97.5 \\
\hline & NO & 6 & 2.5 \\
\hline & Total & $\mathbf{2 4 4}$ & $\mathbf{1 0 0 . 0}$ \\
\hline
\end{tabular}

Table 10: Whether the Organization Identifies with Business Process Reengineering

The findings show that $97.5 \%$ of the commercial banks in Kenya have embraced Business Process Reengineering. This finding is supported by the findings of Ramagopal, Palaniapal, Hemalatha, \& Murugan (2011) that, in a volatile global world (Kenya Inclusive), organizations enhance competitive advantage through Business Process Re-engineering (BPR) by radically redesigning selected processes; and as many organizations undertake BPR, issues in implementing BPR become a major concern and how the severity of these problems relates to BPR success. Setegn (2013) observed that Business Process Reengineering has become useful weapon for any organization that is seeking for improvement in their current organizational performance and intends to achieve organizational objective. Reengineering also helps organizations to throw away their oldfashioned processes to achieve new heights of success (Jemal et al., 2011, as quoted by Setegn, 2013). Reengineering primary goals aimed at to reduce wastage, improve efficiency and ultimately reduce costs (Lotfollah et al., 2012).

According to the findings by Dejan (2011, as quoted by Kheirollahi et al., 2014), the concept of BPR enables modern companies to reconsider and redesign more process of business. Nauman, (2013), observed that the results of research in 2013 showed that, however; there is little agreement between researchers and BPR users, this procedure is a global approach. Kuheirollahi et al., (2014), observed that Business Process Re-engineering has a strong and longstanding approach to improve performance, useful innovation in organization and technologies of e-commerce, which is applied to redesign the processes within the organization such as supply and marketing; In fact, success in e-commerce is affected by BPR (Kheirollahi et al., 2013). Achieng (2014) also observed that Kenya Commercial Bank considered reengineering its business as an important strategic tool to enable it meets its mission of moving from good to great thus enhance its performance. Osano \& Okwena (2015) similarly observed that the Kenyan banking sector has found it important to take up Business Process Reengineering (BPR) in an attempt to greatly improve performance. As Linden, (1994) stated that all organizations, whether service giving or manufacturing, are struggling to meet the tough and new competitive standards of the 1900s speed, quality, efficiency and increased productivity in order to become more competitive, and flexible to meet the desired standard. 


\subsubsection{Extent BPR Factors are Critical in Banks Operations}

The respondents were asked to indicate to what extent they agree that certain BPR factors plays a critical role in business information sharing, business relationships keeping, and conducting business transactions by telecommunications networks in your organization. The results were tabulated as indicated in Table 11.

\begin{tabular}{|c|c|c|c|}
\hline BPR Factors & $\mathbf{N}$ & Mean & $\begin{array}{c}\text { Std. } \\
\text { Deviation }\end{array}$ \\
\hline $\begin{array}{c}\text { A robust platform for modeling and executing process-based applications, } \\
\text { including business rules }\end{array}$ & 244 & 4.37 & .625 \\
\hline $\begin{array}{l}\text { Developing a flow chart for the total business process, including its interfaces } \\
\text { with other value chain activities }\end{array}$ & 244 & 4.29 & .704 \\
\hline $\begin{array}{l}\text { Trying to simplify the process first, eliminating tasks and steps where possible } \\
\text { and analyzing how to streamline the performance of what remains }\end{array}$ & 244 & 4.34 & .723 \\
\hline $\begin{array}{l}\text { Determining which part of the process can be automated; considering } \\
\text { introducing advanced technologies that can be upgraded to achieve the next } \\
\text { generation capability and provide a basis for further productivity gains down } \\
\text { the road }\end{array}$ & 244 & 4.39 & .690 \\
\hline $\begin{array}{c}\text { Evaluating each activity in the process to determine whether it is strategy- } \\
\text { critical or not }\end{array}$ & 244 & 4.24 & .765 \\
\hline $\begin{array}{l}\text { Weighing the pros and cons of outsourcing activities that are non-critical or } \\
\text { that contribute little to organizational capabilities and core competencies }\end{array}$ & 244 & 4.24 & .743 \\
\hline $\begin{array}{l}\text { Designs for performing activities that remain; reorganize the personnel and } \\
\text { groups who perform these activities into the new structure }\end{array}$ & 244 & 4.25 & .702 \\
\hline $\begin{array}{l}\text { Enabling managers to identify business issues, trends, and opportunities with } \\
\text { reports and dashboards and react accordingly }\end{array}$ & 244 & 4.36 & .715 \\
\hline $\begin{array}{c}\text { Providing a system for storing and securing electronic documents, images, and } \\
\text { other files }\end{array}$ & 244 & 4.47 & .733 \\
\hline $\begin{array}{l}\text { Removing intra- and interdepartmental communication barriers through } \\
\text { discussion forums, dynamic workspaces, and message boards }\end{array}$ & 244 & 4.23 & .839 \\
\hline
\end{tabular}

Table 11: Extent BPR Factors are Critical in Banks Operations

The results show that $68 \%$ of the responses were within one standard deviation from the mean as supported by actual standard deviations. The result shows a mean of between 4.24 and 4.47 which indicate "agreement". This implies that BPR Factors are considered in Banks operations. Providing a system for storing and securing electronic documents, images, and other files -content management (with a mean of 4.47 and responses spread within standard deviation of 0.733), has the most critical in banks operations. It involves the administration of digital content throughout its lifecycle, from creation of permanent storage or deletion. It allows users to access system from a remote location 9for example mobile banking), and must be part of every organization's strategy (Mescan, 2014). Study by Rossignoli, Mola and Zardini (2011) found that enterprise content management system optimizes information management in organization memory, perfect decision-making process, and improves company performance through competitiveness. The findings of Osano and Okwena (2015) also established that process and system management seemed to be the most influential factor in banking setting, and it is core in the success of BPR project.

The findings indicate that a robust platform for modeling and executing process-based applications, including business rules -process engine (with a mean of 4.37 and responses spread within standard deviation of 0.625 ) is also considered critical. This implies that the commercial banks put in place software framework that enables the execution and maintenance of process workflow. This provides business interaction and communication between different data/ process source spread across one or more IT applications and services. It also enables high performance flexibility, intensibility, and consistent environment for deploying EAI, Internet B2B, EDI, and business process management projects. Gunasekaran and Kobu (2002) asserted that modelling not only helps to plan reengineering, but also makes implementation of necessary changes to the organization and other related resources easier; that the processes models need to be developed employing e- 
commerce, e-manufacturing and e-service environments, following the operating environment of current manufacturing/ services that have changed the perspective of globalization and the application of information technology.

Developing a flow chart for the total business process, including its interfaces with other value chain activities (with a mean of 4.29 and responses spread within standard deviation of 0.704 ) is also under consideration. This is an approach to changing structure by the organization, that helps the teams involved in the process to understand how it currently works (analyzing and mapping "as is" process). Hamscher (1994) asserted that every company can be seen as a sum of processes that responds to customers' needs by creating, producing, supplying, and invoicing good and services.

Other BPR factors considered critical include: trying to simplify the process first, eliminating tasks and steps where possible and analyzing how to streamline the performance of what remains (with a mean of 4.34 and responses spread within standard deviation of 0.723 ). Determining which part of the process can be automated, considering introducing advanced technologies that can be upgraded to achieve the next generation capability and provide a basis for further productivity gains down the road (with a mean of 4.39 and responses spread within standard deviation of 0.690); Evaluating each activity in the process to determine whether it is strategy-critical or not (with a mean of 4.24 and responses spread within standard deviation of 0.765) -strategy critical activities are candidates for benchmarking to achieve best-in industry performance status; Weighing the pros and cons of outsourcing activities that are non critical or that contribute little to organizational capabilities and core competencies (with a mean of 4.24 and responses spread within standard deviation of 0.743); Design a structure for performing activities that remain, reorganize the personnel and groups who perform these activities into the new structure (with a mean of 4.25 and responses spread within standard deviation of 0.702); Enabling managers to identify business issues, trends, and opportunities with reports and dashboards and react accordingly -Business Analytics (with a mean of 4.36 and responses spread within standard deviation of 0.715 ), indicates that commercial banks in Kenya engage in iterative methodological exploration of organization data, with an emphasis on statistical analysis. This shows that these Commercial Banks are committed to data driven decision. Nderi (2014) found that business analytics had impact on performance of commercial banks in Kenya.

Removing intra and interdepartmental communication barriers through discussion forums, dynamic workspaces, and message boards- collaboration tools (with a mean of 4.23 and responses spread within standard deviation of 0.837) implying effort to support a group of two or more individuals to accomplish a common goal or objectives they have set themselves. From the findings of Hidayanto and Setyady (2014) the use of collaboration tools has positive influence on team performance. According to the findings, the commercial banks takes into consideration, business analysis and information management as a drive to electronic commerce strategy adoption. Similarly, by trying to simplify the process first, eliminating tasks and steps where possible and analyzing how to streamline the performance of what remains; a robust platform for modeling and executing process-based applications, including business rules.

Determining which part of the process can be automated, considering introducing advanced technologies that can be upgraded to achieve the next generation capability and provide a basis for further productivity gains down the road. These are the process excellence/ optimization practices by commercial banks to enable them adopt e-commerce strategy. Developing flow charts for the total business process, including its interfaces with other value chain activities; evaluating each activity in the process to determine whether it is strategy-critical or not; and enabling managers to identify business issues, trends, and opportunities with reports and dashboards and react accordingly; Removing intra- and interdepartmental communication barriers through discussion forums, dynamic workspaces, and message boards are BPR project management practices by commercial banks in Kenya. These findings indicate that commercial banks in Kenya have successfully reengineered their operations around strategically critical business processes.

From the findings, none of the means scores is approximately five (Strongly Agree). This is an indication of BPR practice is still below the excellent required standard, bearing in mind to the fact that the market is very competitive. As quoted by Juma (2017) "Financial experts have said that the Kenyan banking sector is passing through a challenging environment that has never been witnessed before. They say that the prevailing environment might be a fulfillment of the scientific evolution premise of the 'survival for the fittest' where only the strong ones will be able to endure till the end". This is in agreement with the findings by Zhou (2013), who observed that BPR is the only way to carry out e-commerce to SMEs, and it can only be used under the condition that significant rebuilding and innovation are made in organization structure, decision making mode and supply chain management.

Adjei (2013) observed that Ghana Commercial Bank (GCB) had not achieved fully the purpose of the BPR, considering the expenditure of the bank for each year which keeps increasing as against the profit made and when you compare that to its other competitors who with their smaller branch network were able to make profit much larger than GCB. The study also showed that management was committed to the process but because communication was basically one sided i.e. from topdown and lack of an efficient feedback staff were resistant new changes since they saw it rather as an imposition by management. Shemi \& Procter, (2013) observed that the electronic commerce adoption by commercial banks (just as SMEs) requires understanding on the internal resources and what opportunities are available in the external environment, since different organizations have peculiar needs in relation to e-commerce; and various prevailing circumstances will interact differently with the industry and national factors which and various prevailing circumstances will interact differently with the industry and national factors. Study by Muturi (2014), established that increase of hiring of employees in the company and laying off of employees were impacted by BPR quite often; on the other hand, new organizational shared values and beliefs, 
new roles necessitating the acquisition of multiple skills by employees and new customer focused processes were impacted by BPR sometimes.

\subsubsection{Extent BPR Processes Contribution to Electronic Commerce Uses}

The study sought to test how the elemental rethinking and radical redesigning of the business processes have contributed to the bellow uses of internet for purchase and sale of goods and services, including service and support after sale in your organization. The results were tabulated as indicated in Table 12.

\begin{tabular}{|c|c|c|c|}
\hline BPR Processes & N & Mean & Std. Deviation \\
\hline Business Analysis & 244 & 4.31 & .680 \\
\hline Process excellence & 244 & 4.25 & .752 \\
\hline Project Management & 244 & 4.20 & .735 \\
\hline
\end{tabular}

Table 12: Extent BPR Processes Contribute to Electronic Commerce Uses

From the findings it observed that Business Analysis (with a mean of 4.31 and response spread within standard deviation of 0.680) is considered to be the greatest drive to electronic commerce uses. This was followed by process excellence (with a mean of 4.25 and response spread within standard deviation of 0.752). Findings by Wang, Herve and Shen (2012) disclosed that process improvement in commercial banks is dynamic, continuous forward process. That study proposed for a process improvement model which is suitable to Chinese commercial banks and found out the difficulties and countermeasures of application of continuous process improvement to management banks. Project Management (with a mean of 4.20 and response spread within standard deviation of 0.735 ) has the least contribution. The finding by Teixeira and Pereira (2015) shows that if an organization has to succeed, it is a priority to understand that value of making effective projects (right projects) and managing them efficiently (managing them right), that earning on how to invest in the right projects with the best value for money in the right time to market is synonymous to organizational regeneration towards prosperity.

The findings indicate that in order for the Commercial banks to achieve excellent electronic commerce strategy adoption, they are therefore required to do more on project management and process excellence/optimization. The organization must also improve more on Business analysis and information management. Kassahun (2012) observed that that the availability of sufficient financial resources for staff training and retraining, organizational restructuring, benchmarking touring and new reward systems positively contributes to the radical transformation of the underlying structures, reward systems, performance measurement systems, and values and belief systems of a BPR-implementing organization. The knowledge and skills level of BPR personnel, values and beliefs, employee skills and performance measurement and management systems, cross-functional knowledge, change management knowledge, BPR project management knowledge, leadership knowledge, and knowledge of BPR methodology, tools and techniques, positively influence the level of change made to the enabling organisational structure.

Kangogo (2014) observed that aim of BPR is delivering more value to the customer through rethinking of existing processes, use technology to improve data dissemination and decision making, redesigning the functional organization into cross-functional teams. Namatsi (2014) similarly observed that the areas of improvement that BPR helps achieve include improvement of the turnaround timeframe on service delivery, reducing defect rates, increasing accuracy of process instructions, eliminating repetitive tasks, speeding up product development and improving human resource practices. Nangami (2014) asserted that BPR aims to achieve improvements in the contemporary measure of performance that is cost, quality, service and speed. Kawa (2013) observed that the aim of BPR is the redesigning of the work to better support organizational objectives while reducing on the cost implications.

\subsubsection{BPR outcomes Contribution to Electronic Commerce Strategy Adoption}

The study sought to understand whether BPR outcomes contribute to the Use of Internet for Purchase and sale of goods and services, including service and support after sale in your organization. The results were tabulated as indicated in Table 13.

\begin{tabular}{|c|c|c|c|}
\hline BPR Outcomes & $\mathbf{N}$ & Mean & Std. Deviation \\
\hline Several jobs are combined into one & 244 & 4.27 & .842 \\
\hline $\begin{array}{c}\begin{array}{c}\text { Decision-making becomes part of the job of employees (employee } \\
\text { empowerment) }\end{array}\end{array}$ & 244 & 4.21 & .917 \\
\hline $\begin{array}{r}\text { Steps in the processes are performed in natural order, and several jobs get } \\
\text { done simultaneously }\end{array}$ & 244 & 4.25 & .888 \\
\hline
\end{tabular}




\begin{tabular}{|c|c|c|c|}
\hline BPR Outcomes & N & Mean & Std. Deviation \\
\hline $\begin{array}{c}\text { Processes have multiple versions. This enables the economies of scale that } \\
\text { result from mass production, yet allows customization of products and } \\
\text { services }\end{array}$ & 244 & 4.25 & .806 \\
\hline $\begin{array}{c}\text { Work is performed where it makes the most sense } \\
\text { Controls and checks and other non-value-added work are minimized }\end{array}$ & 244 & 4.11 & .843 \\
\hline $\begin{array}{c}\text { Reconciliation is minimized by cutting back the number of external } \\
\text { contact points and by creating business alliances }\end{array}$ & 244 & 4.16 & .965 \\
\hline A single point of contact is provided to customers & 244 & 4.11 & .832 \\
\hline A hybrid centralized/ decentralized operation is used & 244 & 4.14 & .864 \\
\hline
\end{tabular}

Table 13: BPR outcomes Contribution to Electronic Commerce Strategy Adoption

The results show that $68 \%$ of the responses were within one standard deviation from the mean as supported by actual standard deviations. From the findings, several jobs are combined into one (with a mean of 4.27 and responses spread within standard deviation of 0.842) and this decreases overhead and improved control also side effects, eliminates handoffs, delays, and errors made possible by case workers and teams. Second BPR characteristic observed is that decision-making becomes part of the job of employees- employee empowerment (with a mean of 4.21 and responses spread within standard deviation of 0.917). Rather than go up the hierarchy for an answer therefore assumption is no more valid and fewer delays, low over head cost, faster customer response, and greater empowerment for workers. People the ability to do their work: the right information, the right tools, the right training, the right environment, and the authority they need. Information systems help empower people by providing information, tools and training (Zygiaris, 2000).

Study by Ukil (2016) found that satisfied employees provide better quality service; Steps in the processes are performed in natural order, and several jobs get done simultaneously (with a mean of 4.25 and responses spread within standard deviation of 0.888) ensuring job done simultaneously, shorter time for the process, and less rework as a result of simultaneous work. Processes have multiple versions. This enables the economies of scale that result from mass production, yet allows customization of products and services (with a mean of 4.25 and responses spread within standard deviation of 0.806). The multiple version of the same process is needed to meet the requirements of different markets, customers, or solutions; Work is performed where it makes the most sense (with a mean of 4.11 and responses spread within standard deviation of 0.843 ). Work shifts across organizational boundaries; Controls and checks and other non-value-added work are minimized (with a mean of 4.16 and responses spread within standard deviation of 0.965). This is carried out when it makes economic sense; Reconciliation is minimized by cutting back the number of external contact points and by creating business alliances (with a mean of 4.22 and responses spread within standard deviation of 0.832). This is to minimize the number of external contacts points that process has. It reduces chances of receiving inconsistent data/ information that will require reconciliation; A single point of contact is provided to customers (with a mean of 4.11 and responses spread within standard deviation of 0.949) to act as a buffer between the customer and the complex process. Case manager provides the customer with all the information they need; A hybrid centralized/ decentralized operation is used (with a mean of 4.14 and responses spread within standard deviation of 0.864 ). This is about combining the advantages of centralization and decentralization in the same process.

IT enables organization units to act as autonomous units while at the same time enjoy the economies of scale brought about by centralization. The findings by Holberg, Sjogren \& Hellstron (2010) established that asymmetric markets (in terms of the proportion of high ability entrepreneurs) tend to favor centralized banking while decentralized banks seem better at lending in the wake of an economic downturn (high probability of recession). Even through a bank group where decisions are decentralized may end up with portfolio of loans which is relative poorly diversified between regions; the ability to effectively screen potential borrowers may nevertheless give a decentralized bank a lower overall risk in the lending portfolio than when decisions are decentralized. Findings by Berger (2005) raised a conclusion that a large organization might at least to a degree, be able to enjoy the best of both worlds if it sets up the internal structure that achieves the right level of decentralization.

According to this finding, several jobs are combined into one contribute most to the to the use of internet for purchase and sale of goods and services, including service and support after sale in your organization, followed by Processes have multiple versions (This enables the economies of scale that result from mass production, yet allows customization of products and services); then by Steps in the processes are performed in natural order, and several jobs get done simultaneously. According to the findings, work is performed where it makes the most sense, and a single point of contact is provided to customers provides least contribution to the use of internet for purchase and sale of goods and services, including service and support after sale. This indicates how less serious this important aspect of BPR is taken into consideration in the commercial banks. This supported by the findings by Kassahun (2012), BPR implementation problems, such as a lack of top management 
continued support and commitment and BPR team members' discontinuance and lack of autonomy during the BPR project, are factors that directly inhibit the depth of change possible and that indirectly and negatively influence business process performance in the commercial banks in Kenya. This has been adversely mentioned by bank staffs that were interview.

These study findings are consistent with Zygiaris (2000) that Redesign, retooling and re-orchestrating form the key components of BPR that are essential for an organization to focus on the outcome that it needs to achieve. The outcome pursued should be an ambitious outcome. These types of visionary goals require rethinking the way most organizations do business, careful redesign. They will additionally need very sophisticated supporting information systems and a transformation from a traditional organizational structure to a network type organization.

\subsection{Inferential Analysis}

This focuses on evaluating the strengths and direction of relationship between variables inferring findings from the sample to the population (Bryman \& Bell, 2015). In this study, the inferential analysis focuses on evaluating the relationship between business process reengineering and electronic commerce strategy as adopted by commercial banks in Kenya. The multiple linear regression technique was used with the following model being tested:

$Y=\beta_{0}+\beta_{1} X_{1}+\beta_{2} X_{2}+\beta_{3} X_{3}+\varepsilon, \quad$ Model 1

Where $\mathrm{Y}=$ Electronic commerce strategy adoption by commercial banks in Kenya; $\mathrm{X}_{1}=$ Business Analysis; $\mathrm{X}_{2}=$ Process Excellence; $\mathrm{X}_{3}=$ Project Management; $\varepsilon=$ error term. Table 14 presents a summary of the model 1 .

\begin{tabular}{|c|c|c|c|c|}
\hline Model & R & R Square & Adjusted R Square & $\begin{array}{c}\text { Std. Error of the } \\
\text { Estimate }\end{array}$ \\
\hline 1 & $.337(\mathrm{a})$ & .114 & .103 & .523 \\
\hline
\end{tabular}

Table 14: Model 1 Summary

a Predictors: (Constant), Business Analysis, Process Excellence, Project Management.

As the Table 14 shows, R-Square is 0.114 , which indicates that the model explains the $11.4 \%$ of electronic commerce strategy adoption by the commercial banks in Kenya. According to Toole (2013), a model that yields an R Square of above 0.25 is considered to be fit in social science.

Table 15 presents the Analysis of Variances (ANOVA) of the model. The ANOVA test examines the significance of the relationship between the independent variable and the dependent variable by comparing the predicting power of the model with that of the intercept only model (Faraway, 2002).

\begin{tabular}{|c|c|c|c|c|c|c|}
\hline Model & & $\begin{array}{c}\text { Sum of } \\
\text { Squares }\end{array}$ & df & $\begin{array}{c}\text { Mean } \\
\text { Square }\end{array}$ & F & Sig. \\
\hline 1 & Regression & 8.432 & 3 & 2.811 & 10.271 & $.000(\mathrm{a})$ \\
\hline & Residual & 65.678 & 240 & .274 & & \\
\hline & Total & 74.111 & 243 & & & \\
\hline
\end{tabular}

Table 15: ANOVA for the Model 1

a Predictors: (Constant), Business Analysis, Process Excellence, Project Management, b Dependent Variable: Electronic Commerce Strategy as adopted by Commercial Banks in Kenya

The regression model as illuminated in the ANOVA Table 15 predicts the dependent variable significantly well. The statistical significance of the regression model run is 0.000 which is much lower than the study's level of significance of 0.05 . This implies that the overall regression model statistically significantly predicts the outcome variable-electronic commerce as adopted by commercial banks in Kenya.

\begin{tabular}{|c|c|c|c|c|c|c|}
\hline \multirow{3}{*}{ Model } & & \multicolumn{2}{|c|}{$\begin{array}{c}\text { Unstandardized } \\
\text { Coefficients }\end{array}$} & $\begin{array}{c}\text { Standardized } \\
\text { Coefficients }\end{array}$ & t & \multirow{2}{*}{ Sig. } \\
\cline { 3 - 7 } & & $\mathbf{B}$ & $\begin{array}{c}\text { Std. } \\
\text { Error }\end{array}$ & Beta & \\
\hline \multirow{3}{*}{1} & (Constant) & 3.169 & .236 & & 13.421 & .000 \\
\cline { 3 - 7 } & Business Analysis & -.006 & .066 & -.007 & -.090 & .928 \\
\cline { 2 - 7 } & Process Excellence & .173 & .060 & .236 & 2.885 & .004 \\
\cline { 2 - 7 } & Project Management & .108 & .062 & .143 & 1.750 & .081 \\
\hline
\end{tabular}

Table 16: Regression Coefficients for Model 1

a Dependent Variable: Electronic commerce Strategy as Adopted by Commercial Banks in Kenya 
Table 16 presents the Analysis of Variances (ANOVA) of the model. The ANOVA test examines the significance of the relationship between the independent variable and the dependent variable by comparing the predicting power of the model with that of the intercept only model (Faraway, 2002). Based on Table 16, the estimated regression equation was: Electronic commerce strategy as adopted by commercial banks in Kenya

$$
\mathrm{Y}=3.169-0.006 \mathrm{X}_{1}+0.173 \mathrm{X}_{2}+0.108 \mathrm{X}_{3} \quad \text { Model } 1
$$

\subsubsection{Influence of Business Analysis on Electronic Commerce Strategy Adoption by Commercial Banks in Kenya}

The first objective of the study was to examine the influence of Business Analysis on the electronic commerce strategy as adopted by commercial banks in Kenya. As shown in Table 16 shows the t-statistics for business analysis yielded a p-value of 0.928 . Since this $p$-value is greater than 0.05 , we fail to reject the null hypothesis and affirms that there is no statistically significant relationship between the Business Analysis and electronic commerce strategy adoption by commercial banks in Kenya at 0.05 level of significance. This is consistent with the findings of Ambira and Kemoni (2011) established that there are inadequate records management practices and systems, the lack of which undermines the risk management function. Grant (2016) also established that some business analysis techniques are used more than others depending on the fit between the technique and the problem. Other techniques are preferred due to their versatility, easy to use, and flexibility. Some are difficult to use requiring skills that analysts do not possess. Problem analysis and business process analysis and activity elimination techniques are preferred for process improvement projects, and technology analysis for technology problems. Root Cause Analysis (RCA) and Activity-Based Costing (ABC) are seldom used. RCA requires specific skills and ABC is only applicable for discrete business activities. Karim (2011) established that the organization management does not always recognize the information needed, while the information professionals often do not comprehend and are aware of management in order to produce relevant information for the managers they serve. William Dudley (2014), the President of the New York Federal Reserve Bank, observed that the 20th and 21st centuries have seen a vast number of banking process failures from technical, to ethical and individually driven downfalls. Although we are led to believe banks are the best place of protection for our finances, it is evident that this is not always the case. Small systems errors as well as occasional internal fraud can cause failures which cost industries and individuals tens of billions very quickly.

\subsubsection{Influence of Process Excellence on Electronic Commerce Strategy Adoption by Commercial Banks in Kenya}

The second objective of the study was to examine the influence of process excellence on electronic commerce strategy as adopted by commercial banks in Kenya. As shown in Table 16 above the t-statistics for structural design yielded a p-value of 0.004. Since this p-value is less than 0.05 , we reject the null hypothesis and affirm that there is statistically significant relationship between the process excellence and electronic commerce strategy as adopted by commercial banks in Kenya at 0.05 level of significance. This is consistent with the findings by Wang, Herve and Shen (2012) that the process improvement in commercial banks is a dynamic, continuous forward process. Nyaanga (2007) established that the major barriers encountered by banks in the increased use of e- commerce in business process management are conservative organizational cultures and lack of industry standards and there are many issues of e-commerce which have implications on banks business process management such as retail transfers e-payments, use of electronic ID, security of operations, internet banking, electronic signatures and sharing of a lot of mobile applications. The research by Saeed and Nasar (2016) proposed a process improvement model through careful analysis and research that is adjustable to the commercial banks of Pakistan and pick out the problems and preventives of implementation of continuous process improvement to management banks. Hargeus, Trinkaus and Eiber (2013) also established that Excellence in Operations can only be achieved when operations are linked with the basic services customers expect. This approach will address some of the basic banking processes that matter most to customers, creating a foundation for more strategic improvements that will also allow more innovative changes thereby achieving greater benefits. Waithira (2013) established that Efficiency and effectiveness is the core drive of commercial banks in Kenya both in the domestic and international markets.

\subsubsection{Influence of Project Management on Electronic Commerce Strategy Adoption by Commercial Banks in Kenya}

The third objective of the study was to examine the influence of project management on electronic commerce strategy as adopted by commercial banks in Kenya. As shown in Table 16 above the t-statistics for project management yielded a pvalue of 0.081 . Since this p-value is greater than 0.05 , we fail to reject the null hypothesis and affirm that there is no statistically significant relationship between the project management and electronic commerce strategy as adopted by commercial banks in Kenya at 0.05 level of significance. Astudy by Ochwoto (2017) recommended that project management office should be viewed as strategic pillar of the bank, the bank should capitalize on project management for digitization, staff should be encouraged to work as a team through all the processes and phases of core banking projects, top management should engage in consistent communication with project teams and support by sufficient human and material resources, project managers who receive the necessary training are able to perform hence training gives the employee a greater understanding of their responsibilities within their role and adoption of monitoring and evaluation tools, evaluation analyzes why intended results were or were not achieved while monitoring focuses in particular on efficiency. The study by Kariuki and Chege (2014) found that whereas the outside world sees Commercial Bank of Africa's (CBA's) IT project delivery model as highly successful, CBA project stakeholders themselves feel that their IT projects are rarely successful as none of them are 
completed on time or within budget. The study further found that realization of business objectives is the single most important determinant of project success at CBA with top management feeling that whereas they were very clear on their business objectives before pursuing the IT projects, none of the projects completed during the survey period had delivered on their intended business benefits. Top management support to IT projects was found to be very strong at CBA but this has not resulted in successful projects with $74 \%$ of survey respondents blaming poor project delivery to project manager incompetence.

\subsubsection{Estimated Regression Equation}

Based on Table 16, the estimated regression equation was: Electronic commerce strategy adoption by commercial banks in Kenya.

$$
(\mathrm{Y})=3.169-0.006 \mathrm{X}_{1}+0.173 \mathrm{X}_{2}+0.108 \mathrm{X}_{3}
$$

The equation shows that process excellence has the most significant influence on electronic commerce strategy as adopted by commercial banks in Kenya. The beta coefficient of 0.173 implies that, holding other factors constant, increasing quality of process excellence by 1 unit would increase Electronic commerce strategy adoption by commercial banks in Kenya by 0.173 units. However, Business Analysis has a negative influence on Electronic commerce strategy as adopted by commercial banks in Kenya with beta coefficient (-0.006) suggesting that improving business analysis by 1 unit would decrease the level of Electronic commerce strategy as adopted by commercial banks in Kenya by 0.006 units. Project Management has a positive influence on electronic commerce strategy as adopted by commercial banks in Kenya with a beta coefficient of 0.108 suggesting that improving project management by 1 unit would increase Electronic commerce strategy as adopted by commercial banks in Kenya by 0.108 units.

\section{Summary of Findings, Conclusion and Recommendations}

\subsection{Summary of Findings}

The study employed descriptive survey design where a sample of 384 respondents was drawn from a population of 36,923 using simple random sampling. A total of 384 questionnaires were distributed to the respondents, 244 were dully filled and returned to the researcher, translating to a response rate of $63.54 \%$. The collected data was analyzed using both descriptive and multiple linear regression technique.

The findings indicate show that that $97.5 \%$ of the commercial banks in Kenya have embraced Business Process Reengineering, meaning they are organized based on processes. $2.5 \%$ of the commercial banks have not and this indicates that they are not using informational technology to breakdown functional buriers and creating work systems based on business processes, product or output rather than on functions or inputs. According to the findings, commercial banks provide system for storing and securing electronic documents, images, and other files; they weighing the pros and cons of outsourcing activities that are non-critical or that contribute least to organizational capabilities and core competencies. Similarly, the commercial banks are engaged in simplifying the process first, eliminating tasks and steps where possible and analyzing how to streamline the performance of what remains; they have a robust platform for modeling and executing process-based applications, including business rules. The commercial banks determine which part of the process can be automated, and considers introducing advanced technologies that can be upgraded to achieve the next generation capability and provide a basis for further productivity gains down the road. This implies that the banks are engage in customer service oriented processes aimed to eliminate customer complaint though not to the market expectations.

\subsubsection{Influence of Business Analysis on Electronic Commerce Strategy Adoption by commercial banks in Kenya}

According to the findings, there is no statistically significant relationship between the Business Analysis and electronic commerce strategy as adopted by commercial banks in Kenya, and Business Analysis has a negative influence on Electronic commerce strategy as adopted by commercial banks in Kenya. The commercial banks are identified to have problems with BPR factors implementation including enabling managers to identify business issues, trends, and opportunities with reports and dashboards and react accordingly, though they consider these important in their normal operations.

\subsubsection{Influence of Process Excellence on electronic commerce strategy as Adopted by commercial banks in Kenya}

According to this finding, there is statistically significant relationship between the quality of Process Excellence and electronic commerce strategy as adopted by commercial banks in Kenya. The commercial banks in Kenya combines several jobs into one; control and checks and other non-value adding works are minimized; the processes have multiple versions; steps in the processes are performed in natural order; several jobs get done simultaneously. According to the findings, work is performed where it makes the most sense, and a single point of contact is provided to customers. Hybrid centralized and decentralized operation is used and reconciliation is minimized by minimizing back the number of external contact point and by creating business alliance. Similarly, the banks carry out as robust platform for modeling and executing process-based applications including business rules 
5.1.3. Influence of Project Management Effectiveness on Electronic Commerce Strategy as Adopted by Commercial Banks in Kenya

According to the findings, there is no statistically significant relationship between the project management and electronic commerce strategy as adopted by commercial banks in Kenya. From the findings, the commercial banks take into consideration BPR project management practices, but seem not to operate at optimum when developing flow charts for the total business process, including its interfaces with other value chain activities; evaluating each activity in the process to determine whether it is strategy-critical or not; and remove intra- and interdepartmental communication barriers through discussion forums, dynamic workspaces, and message boards.

\section{Conclusion}

Based on the findings of the study, the researcher has drawn several conclusions which are presented in this section following the order of the objectives of the study

\subsection{Influence of Business Analysis on Electronic Commerce Strategy Adoption by commercial banks in Kenya}

The research finding has led to the conclusion that Business Analysis has negative and not significant influences on electronic commerce as adopted by commercial banks in Kenya. The BPR factors as implemented have a negative impact on electronic commerce strategy as adopted by the commercial banks in Kenya.

\subsection{Influence of Process Excellence on electronic commerce strategy as Adopted by commercial banks in Kenya}

The research finding has led to the conclusion that Process Excellence has a positive and significant influence on electronic commerce strategy as adopted by commercial banks in Kenya.

\subsection{Influence of Project Management Effectiveness on Electronic Commerce Strategy as Adopted by commercial banks in Kenya}

The research finding has led to the conclusion that banks project management has a positive and not significant influence on electronic commerce strategy as adopted by commercial banks in Kenya. This could have been contributed by failure by commercial banks to successfully develop flow charts for the total business process, including its interfaces with other value chain activities; failure to successfully evaluating each activity in the process to determine whether it is strategycritical or not; and failure to successfully remove intra- and interdepartmental communication barriers through discussion forums, dynamic workspaces, and message boards seem has caused the insignificant influence on the electronic commerce strategy adoption.

\section{Recommendations}

Based on the conclusions the study has drawn several recommendations which are presented in this section following the order of the objectives of the study.

- The study recommends that the banks should change their strategic approach to Business Analysis, so that a positive impact on electronic commerce strategy could be achieved (Total shift to a new strategic direction). This will involve all stakeholder consultation, taking into consideration the various strategic business analysis approaches. The commercial banks must avoid the way they conduct the business analysis if they have to achieve higher levels of electronic commerce strategy adoption.

- The study also recommends for improvement in all process excellence approaches. This study recommends improvement in BPR processes and factors. This will enable a more positive influence on electronic commerce strategy adoption by the commercial banks. The commercial banks must embrace the principle of continuous improvement in process excellence.

- The study recommends for serious improvement in project management of our commercial banks. This could involve hiring right staff with the right competence, training and development. This will enable all projects to be carried out within required levels of constraints.

\section{Suggestions for Further Studies}

The current study was limited to commercial banks in Kenya in Kenya. Further studies should consider exploring other non-commercial banks so as to support the generalization of the findings. Future studies can also focus on the influence of other organizational capabilities.

\section{References}

i. Achieng, N. D. (2014) Business Process Reengineering Practices and Performance of Kenya Commercial Bank. Unpublished MBA Thesis. University of Nairobi.

ii. Adjei, K.S (2013) Business Process Reengineering (BPR) In the Financial Services Sector: A Case Study of Ghana Commercial Bank (GCB) Limited. European Journal of Business and Management, 5(29) 
iii. Afande, O. F. (2013). Effects of strategic management practices on performance of financial institutions in Kenya: A case of Kenya Post Office Savings Bank, International Journal of Business Management and Administration, 2(6) 122141.

iv. Alam, S., \& Noor, M. K. M. (2009). ICT adoption in small and medium enterprises: an empirical evidence of service sector in Malaysia. International Journal of Business and Management, 4(2), 112-125.

v. Ambira, C.M. \& Kemoni, H., 2011, 'Records management and risk management at Kenya Commercial Bank Limited, Nairobi', SA Journal of Information Management 13(1).

vi. Bagchi, K. (2007). Empirical Testing Factors that Drive ICT Adoption in Africa and OECD set of nations. Issues in information system , 45-52.

vii. Baruch Y, \& Holtom, B. C. (2008). Survey response rate levels and trends in organizational research. Human Relation, 61(8), 1139-1160.

viii. $\quad$ Berger, A.N., Miller, N.H., Petersen, M.A., Rajan, R.G., Stein, J.C., (2005) Does function follow organizational form? Evidence From The Lending Practices of Large and Small Banks. Journal of Financial Economics 76, 237-269.

ix. $\quad$ Bryman, A., \& Bell, E. (2015). Business research methods. Oxford University Press, USA.

x. Central Bank of Kenya, (CBK) (2015). Bank Supervision report. Kenyan banking Sector for the period ended December 2015. Retrieved from https:/ / www.centralbank.go.ke

xi. Chandran. (2004). Research Methodology. London: Worls Scientific Ltd

xii. Chege, S. (2014). Factors Affecting The Success Of Information Technology Projects Within The Kenyan Banking Industry: Commercial Bank Of Africa. Nairobi: Kenyatta University.

xiii. Chiware, E.R. \& Dick, A.L. (2008). The use of ICT in Namibia SME sector to access business information service: the electronic library, 26(2), 145-157.

xiv. CIMA. (2010). CIMA Sector Report. Global Banking sector: current issues. London: World congress of Accountants.

xv. Cooper, D. R., \& Emory, C. W. (2008). Business Research Methods (5thed). USA: Richard D. Irwin.

xvi. Cooper, D. R., \& Schindler, P. S. (2003). Business research methods (8th ed.). New Delhi: TATA McGraw Hill Publisher.

xvii. $\quad$ Cooper, D. R., \& Schindler, P. S. (2013). Business Research Methods (12 th edition) New York: McGraw Hill.

xviii. $\quad$ Doherty, N.F., \&Ellis-Chadwick, F.(2003) "The relationship between retailers' targeting and e-commerce strategies: an empirical analysis", Internet Research, 13(3) 170-182.

xix. Duncombe, R., \& Heeks, R. (2007). Information and communication technologies and small enterprise in Africa. Lesson from Botswana. Retrieved from http:// www .sed.manchester .ac.uk/ idpm/ research/is/ ictsme/ full/ section2.doc.

xx. Faraway, J. (2002). Practical Regression and Anova using R. Retrieved on Wednesday 17th August, 2011@ www.rproject.org .

xxi. Gakure, R. W. \& Kingongo, G. (2005). The Relationship Between Education and 119 Business Performance of Women Owned Small Enterprises in Kenya. Proceedings of 2005 scientific, technological and industrial conference 27th-28th October. Nairobi: Publisher JKUAT.

xxii. Gakure, R., Keraro, V., Okari, H., \& Kiambati, K. (2012). Emerging Trends Shaping Contemporary Business Strategy. Prime Journal of Business Administration and Management, 2(9), 673-679.

xxiii. Gakure, Roseyln (2003). "Factors Affecting Women Entrepreneurs' Growth Prospects in Kenya." Prepared for the International Labour Organization (ILO), Geneva, November.

xxiv. Ghobakhloo, M., Arias-Aranda, D. \& Benitez-Amado, J. (2011a). Information technology implementation success within SMEs in developing countries: An interactive model, POMS 22nd Annual Conference: Operations management: The enabling link Reno, Nevada, U.S.A.

xxv. Ghobakhloo, M., Arias-Aranda, D. \& Benitez-Amado, J. (2011b). Adoption of e-commerce applications in SMEs, Industrial Management \& Data Systems, 111 (8)1238 - 1269.

xxvi. $\quad$ Grant, D. (2016) "Business Analysis Techniques In Business Reengineering", Business Process Management Journal, 22 (1), 75-88

xxvii. Gunasekaran, A \& Kobu, B (2002) Modelling and analysis of business process reengineering. International Journal of Production Research, 40(11), 2521-2546

xxviii. $\quad$ Gupta, S.P. (2005). Statistical Methods. (34th Edition). New Delhi: Sultan Chand \& Sons Publishers

xxix. Hager, M.A., Wilson, S, Pollak, T.H., Rooney, P.M (2003).Response Rate for male survey of non profit organization: review and empirical test. Non profit and voluntary sector quarterly, 32(2), 252-267.

xxx. Hamscher, W. (1994). AI in business process reengineering. AI Magazine. Winter 1994, 15(4).

xxxi. Hargeus, Trinkaus, \& Eiber (2013) Excellence in Operations: Helping Banks Regain Customer Trust, 5(3), Retrieved from ww.eg.com/ performance

xxxii. Harindranath, G. R. (2008). ICT in Small Firms: Factors affecting the doption and use of ICT in Southeast England SMEs. Proceedings of the 2008 European Conference of Information Systems (ECIS). Galway, Ireland: ECIS.

xxxiii. Harper, L. M. (2003). Reseatch Methodology: step by step guide for beginners. London: Sage Publishers.

xxxiv. Hidayanto, A. N. (2014) Impact Of Collaborative Tools Utilization On Group Performance In University Students, The Turkish Online Journal of Educational Technology,13(2) 
xxxv. Holmberg, U., Sjögren, T,. \& Hellström, H. (2010) Comparing Centralized and Decentralized Banking: A Study of the Risk-Return Profiles of Banks Comparing Centralized and Decentralized Banking, Umeå University

xxxvi. Huq, Z., \& Martins, T. N. (2006) The Recovery of BPR implementation through an ERP approach: A hospital case. Business process management journal, 12(5), 576-587.

xxxvii. Kangogo, J. (2014) Process Element of TQM and Operational Performance of Airlines in Kenya. Journals in Business \& Management, 2(3), 65-70.

xxxviii. Karim, A. J. (2011).The Significance of Management Information Systems for Enhancing Strategic and Tactical Planning. Journal of Information Systems and Technology Management 8(2)

xxxix. Kasiva, M. V. (2012). The impact of risk based audit of financial performance in commercial banks in Kenya. Unpublished Thesis, University of Nairobi.

xl. Kathuku, J. K., Ngugi, N. P., \& Muturi, W.M. (2017). Influence of Commercial Banks' Capacity Building Lending Strategy On Growth Of SMES In Kenya. Journal of Business and Strategic Management. 2(1), 20 - 34.

xli. Kawa, F. (2013) Automation and Operational Performance in Hydro Electric Power Generation Sector. International Multidisciplinary Journal, 2(3), 25-30.

xlii. $\quad$ Kheirollahi1, F., Veysi1 F.S., Majidipour, A., \& Majidipour, P. (2014). A Study of Using BPR and TQM in E-commerce. European journal of natural and social science, 2(3)

xliii. Kim, W. G., \& Cha, Y. (2002). Antecedents and consequences of relationship quality in hotel industry. Hospitality Management, 21, 321-338.

xliv. KMPG. (2015, February). Governance of Central Banks: Taking financial oversight to the next level. KPMG International Report.

xlv. Kombo, D.K. and Tromp, D. L. A. (2006). Proposal and Thesis writing: An introduction. Nairobi: Pauline’s Publications Africa

xlvi. Kothari, C. R. (2004). Research Methodology: Methods and Techniques. New Delhi: New Wage International Limited.

xlvii.

xlviii. KPMG. (2015). Banking in Sub-Saharan African Sector Report. KPMG.

Lebaking, C. O. \& Phalare, K, D. (2001). The Consequences of Change for Graduate Employment, Paris Bilton Publisher Likert, R. (1932). Atechnique of measuring Attitutde: Resus Likert issues 140 of archives of psychology. New York.

1. Linden, R. M. (1994). Seamless Government, A practical guide to Reengineering in the public sector. An Francisco: Jossey-Bass Inc.,

li. Liu, X. \& Buck, T. (2007). Innovation competitive advantage and channels for international technology spillovers: evidences from Chinese high-tech industries. Research Policy, 36, 355-366.

lii. Looi, H. (2004). A model of factors influencing electronic commerece adoption among small and medium entreprises in Brunei Darussalam International. journal of information technology .

liii. Looi, H. C., (2005). A Model of Factors Influencing Electronic Commerce Adoption among Small and Medium Enterprises in Brunei Darussalam: International Journal of Information Technology and Management, 10, 1, 72-87.

liv. Lotfollah N., Ziaul H., Seyed M.A., \& Saeedreza, H. (2012). Impact of IT on process improvement: Journal of emerging trends in computing and information sciences. 3(1).

lv. Majid, M. A., Yusoff, W.F.M., Sapolin, A. R. (2015). Women as skilled labour in the construction industry in Malaysia: potential and constraints. E-proceeding of the national conference on social science research, 8-9 June 2015.

lvi. Malhotra, N. K. (2004). Marketing Research: An Applied Orientation. Upper Saddle River, NJ: Pearson Education.

lvii. $\quad$ Malhotra. (2011, April 7). Business Process Design. Retrieved from http:/ / www.computing.dcu.ie/ mcrane/ CA441/ BP_01_BPRIntroductionLectureNotes.pdf

lviii. Manueli, K., Latu, S., \& Koh, D. (2007). ICT Adoption models.20th Annual Conference of the National Advisory Committee on Computing Qualifications (NACCQ), Nelson, New Zealand. Retrieved from http:/ / www.naccq.ac.nz.

lix. Masanja V.G (2010). Increasing Women's Participation in Science, Mathematics and Technology. Education and Employment in United Nations Division for the Advancement of Women (DAW, part of UN Women). Africa. Expert group meeting Gender, science and technology.

lx. Mayer, D. M., Kuenzi, M., \& Greenbaum, R. L. (2010). Examining the link between ethical leadership and employee misconduct: The mediating role of ethical climate. Journal of Business Ethics, 95, 7-16.

lxi. McKinsey Global Institute (2015). A labour market that works: connecting talent with opportunity in the digital age. Wasington DC: McKinsey \& Company.

lxii. Mudanya, R (2014) Effects of diversity management on performance of technical university of Mombasa. Unpublished thesis, University of Nairobi.

lxiii. $\quad$ Mugenda, M. O., \& Mugenda, G. A. (2003). Research Methods: Quantitative \& Qualitative Approach. Nairobi: Laba Graphics Services.

lxiv. Mugenda, M. O., \& Mugenda, G. A. (2003). Research Methods: Quantitative \& Qualitative Approach. Nairobi: Laba Graphics Services.

lxv. Muhammad-Nauman, H., \& Attaullah, S.(2013). Business Process Reengineering: Literature Review of Approaches and Applications, Proceedings of 3rd Asia-Pacific Business 
lxvi. Mundia, M. M. (2014). Factors Influencing Adoption of Information Communication Technology Among Small and Medium Enterprise in Nairobi County, Unpublished thesis, Kabarak University.

lxvii. $\quad$ Murphy, R. (2011), Strategic Planning in Irish Quantity Surveying Practices. Unpublished Doctoral Thesis submitted to Edinburgh Business School, Herriot-Watt University, UK. Retrieved from http:/ / arrow.dit.ie/ beschreoth/ 4/ .

lxviii. Mutula, S. M., \& Brakel, P. (2007). ICT skills readiness for the emerging global digital economy among small businesses in developing countries. Case study of Botswana. Emerald Group Publishing Limited 25(2), 231-245.

lxix. $\quad$ Muturi, W. (2014). Factors affecting adoption of mobile banking in Kenya commercial banks, KCB Biashara Banking Launch.

lxx. Namatsi, O. (2014) E Purchasing and Operational Performance of Commercial State Corporations in Kenya. Journal of International Business Studies, 2(3), 78-84

lxxi. Nangami, M. N. (2014). Employee Trainning and Operational Performance of Firms in the Financial Services Sector in Kenya. Journal of Business and Management, 2(1), 45-50.

lxxii. Nderi (2014) Business Analytics and Performance of Commercial Banks in Kenya. Unpublished MBA Thesis. University of Nairobi.

lxxiii. Netherlands Development Organisation (2017). Gender Analysis of Women's Economic Empowerment in Kenya. Summary of findings Kenya.

lxxiv. Ngugi (2016). More women needed to hold top jobs in banks. Daily Nation, August 2016. Retrieved from gngingi@ke.nation media.com

lxxv. Ngumi, P.M (2013) effect of bank innovations on financial performance of commercial banks in kenya. Research Thesis, Nairobi: Unpublished PhD Thesis, Jomo Kenyatta University of Agriculture and Technology.

lxxvi. $\quad$ Nunnally, J. C. (1978). Psychometric theory (2nd ed.). New York: McGraw-Hill.

lxxvii. $\quad$ Nyaanga O. Richard (2007)The Effects Of E-Commerce Adoption On Business Process Management In Commercial Banks In Kenya. Unpublished MBA Thesis. University Of Nairobi.

lxxviii. Nyakoi (2016). Influence Of Monitoring And Evaluation Strategy On The Implementation Of Ruralelectrification Authority Projects In Tharaka Nithi County Kenya. Unpublished Thesis. The University Of Nairobi.

lxxix. Ochwoto, S. (2017). Factors Influencing Core Banking Project Delivery By Commercial Banks In Kenya: Case Of Equity Bank Limited, Strategic Journal of Business \& Change Management, 4(2)

lxxx. Orodho. (2003). Research Methododology. A step by step guide for beginners (2nd ed.). London: Sage Publishers.

lxxxi. Osano, H. N. \& Okwena, D. M. (2015) Factors Influencing Performance of Business Process Reengineering Projects in Banks in Kenya: Case of Kenya Commercial Bank. Journal of US-China PublicAdministration, November, 12(11) 833844.

lxxxii. $\quad$ Oso, W.Y., \& Onen, D. (2005). A general guide to writing research proposal and reports. A hand book for beginning Researchers, ( 2nd ed.). Makerere University press. Kampala, Uganda

lxxxiii. $\quad$ Osoro. (2015, june). Business Daily , p. 1.

lxxxiv. Otiso, K.N., \& Simiyu, N.G. (2017). Assessing the effects of technological capabilities in firm performance: A case of study of Nzoia Sugar Company. Industrial engineering letters, 7(5).

lxxxv. Otuya, R., Kibas, P.,Gichara, R. \& Martin, W. (2013) Entrepreneurship education: influencing students entrepreneurship intentions. International journal of innovative Research and studies, 2 94), 132-148.

lxxxvi. Patti,J. R. (2009) Hand book of Human Services Management, (2nd ed). New Delhi: SAGE Publication, Inc.

lxxxvii. Raguz, I. V. \& Sekan, S. B. (2015). The role of leadership in organizational adaptation process. University of Dubrovnik. JEL Classification: M21.

lxxxviii. $\quad$ Rahman, S., Rafiq, R. B. \& Momen, M. A. (2009). Impact of Micro-Credit Programs on Higher Income borrowers: Evidence from Bangladesh, International Business \& Economics Research Journal, 8 (2), 119-24

lxxxix. Rajagopalan, N. A., Rasheed, M.A. \& Datta, D. K. (2003). Strategic decision processes: Critical review and future directions. Journal of Management, 19(2), 349-384.

xc. $\quad$ Ramanigopal, C.S., Palaniappan, G., Hemalatha, N., \& Murugan, T. (2011) Business Process Reengineering and its Applications. International Journal of Management Research and Review. 1(5)

xci. Randoy, T., Thomsen, S., \& Oxelheim, L. (2006). A Nordic perspective on corporate board diversity. Age, 390, 0-5428

xcii. $\quad$ Rayport, J. F., \& Sviokla, J.J. (1994).Managing in the Market Space. Harvard Business Review, 72(6), 141-50.

xciii. Rayport, J.F.,\& Sviokla, J.J.(1995).Exploiting the virtual value chain. Harvard Business Review, 73(6), 75-85.

xciv. Republic of Kenya (2007). Kenya vision 2030: A globally competitive and prosperous Kenya. Nairobi: Government printer.

xcv. Rose, R.C., Haslinda, A. \& Ismad, A. I. (2010). A review on the relationship between organizational resources, competitive advantage and competitive advantage. Journal of International Social Research, 3(11), 488-498.

xcvi. Rossignoli, C., Zardini, A., Mola, L., Brocke, J. M. (2011) The ECM's Role and Contribution in Decision-Making Processes. Journal of Decision Systems, 19(10).

xcvii. Saeed, M., \& Nasar, A. (2016). Continuous Process Improvement (Cpi) In Pakistani Banking Sector For Improving Overall Performance, Journal of Business \& Financial Affairs, 5(3) 
xcviii. $\quad$ Saunders, M., Lewis, P. \& Thornhill, A. (2003). Research methods for business students. (3rd ed.). New York: Prentice Hall.

xcix. $\quad$ Saunders, M., Lewis, P. \& Thornhill, A. (2007). Research methods for business students. (4th ed.). London: Prentice Hall.

c. Saunders, M., Lewis, P. \& Thornhill, A. (2009). Research Methods for Business Students (5th Ed). USA: Prentice Hall.

ci. Seifers, K., Puddy, R., Warren, J., \& Roberts, M. (2002). Reporting of demographics, Methodology and Ethical Procedures in Journals in Paediatric and child psychology. Journal of Paediatric Psychology, 27 (1), 19 - 25

cii. Sekaran, U. (2003). Research methods for business: A skill building approach. New York: Wiley.

ciii. Sekaran, U., \& Bougie, R. (2010). Research Methods for Business. UK: John Wiley \& Sons Ltd.

civ. Sekeran, U. (2000). Research methods for business: a skill building approach, (3rd Ed.). New York: John Wiley and Sons, Inc.

cv. Setegn, D (2013). Assessing The Effect Of Business Process Reengineering On Organizational Performance: A Case Study Of Bureau Of Finance And Economic Development (Bofed), Oromia Regional State, Ethiopia, Journal of Arts, Science \& Commerce, IV(1)

cvi. Shemi (2012) Factors Affecting E-commerce Adoption in Small and Medium Enterprises: An Interpretive Study of Botswana. Unpublished PhD Thesis. University of Salford

cvii. $\quad$ Sheninger, E.C \& Murray, C. T. (2017). Learning transformed: 8 keys to designing tomorrow's school today. New York: ASCD, 2017.

cviii. $\quad$ Sophonthummapharn, K. \& Danberg, T. (2005). Leadership styles and e-commerce adoption and analysis of Thi food exporters. Unpublished Thesis, Blekinge Institute of Technology.

cix. Sufian, F., Chong, R.R. (2008), Determinants of bank profitability in a developing economy Empirical evidence from the Philippines. Asian Academy of Management Journal of Accounting and Finance (AAMJAF), 4(2), 91-112.

cx. Tan, K. S. (2009). Internet based ICT adoption: evidence from Malaiysian SMEs. Industrial Management and Data Systems 109 (2) , 224-244.

cxi. Tan, K. S. (2009). Internet based ICT adoption: evidence from Malaiysian SMEs. Industrial Management and Data Systems $109(2), 224-244$.

cxii. Tan, M, T. (2000). Factor Influencing the adoption of internet banking. Journal of Association for Information Systems , $1(5), 1-42$.

cxiii. Tarabishy, A., Solomon, G., Fernald Jr., L.W. \& Sashkin, M. (2005) The Entrepreneurial leader's impact on the organization's performance in dynamic markets. Journal of Private Equity, 8(4): 20-29.

cxiv. Teixeira, C.S.B. \& Pereira, L.L.F. (2015) Pereira Diamond: Benefits Management Framework. The International Journal Of Business \& Management, 3(3)

cxv. Ukil (2016) The Impact Of Employee Empowerment On Employee Satisfaction And Service Quality: Empirical Evidence From Financial Enterprizes In Bangladesh. Verslas: Teorija ir praktika / Business: Theory and Practice, 17(2): 178-189

cxvi. Ulrich, D., \& Wiersema, M. F. (1989). Gaining strategic and organizational capability in a turbulent business environment. The Academy of Management Executives, 3, 115-122.

cxvii. $\quad$ Ulrich, S. (2007). Leadership brand. London: Howard Buiness Press.

cxviii. Ute, E.K (2012) Promotion of Education and Employment. Frankfurt: Bildung Entwicklong.

cxix. Varadarajan, P. Y. (2002). Marketingg strategy and the internet: an organizing framework. journal of the academy of marketing science , 30 (4), 296-312.

cxx. Wachudi, E.J \& Mboya, J. (2009). Effects of board gender diversity on the performance of commercial banks in Kenay. European scientific journal, 8(7).

cxxi. Waiganjo, E. (2013). Relationship between strategic human resource management and firm performance of corporate institutions. Unpublished PhD Thesis. Juja. Jomo Kenyatta University of Agriculture and Technology.

cxxii. Waithira, C. A. (2013) Strategies Adopted by Commercial Banks in Kenya to Management Service Quality. Unpublished MBA Thesis. University of Nairobi.

cxxiii. Wang, C. L, \& Ahmed, P. K. (2007). Dynamic capabilities: A review and research agenda. International Journal of Management Reviews, 9, 31-51.

cxxiv. Wang, L., Herve, B. G., \& Shen, Y. (2012). Continuous Process Improvement in Banking Sector And A Model Design For Performance Enhancement. International Journal of Business and Management, 7(2).

cxxv. Wanyoike, D. M. (2013). Determinant of information communication technology as adopted by formal small entreprises in urban Kenya. Project. Nairobi: Unpublished PhD Thesis, Jomo Kenyatta University of Agriculture and Technology.

cxxvi. Wanyoike, D. M., Mukulu, E., \& Waititu, A. G. (2012). ICT attributes as determinants of E-Commerce As adopted by formal small enterprises in Urban Kenya. international journal of Business and Social Science , 3 (23).

cxxvii. Wensley, R. \& Day GS. (1988). Assessing advantage: a framework for diagnosing competitive superiority. Journal of Strategic, 52(2), 1 - 20.

cxxviii. Wernerfelt, B. (1984). A resource-based view of the enterprise. Strategic Management Journal, 5(2), 171 - 180.

cxxix. World Bank (2010). World Development Indicators. Washington, DC: World Bank. 
cxxx. Yulk \& Mahsud, R. (2010). Why flexible and adaptive leadership is essential. Consulting psychology journal: practice and research. 62(2), 81-93.

cxxxi. Yulk, G., Mahsud, R. (2010). Why flexible and adaptive leadership is essential. Practice and Research. American Psychological Association. Consulting psychology Journal, 62(2) 81-93

cxxxii. Zhang, Z., Waszink, A., \& Wijngaard, J. (2000).An instrument for measuring TQM implementation for Chinese manufacturing companies. International Journal of Quality and Reliability Management, 17(7), 730-755.

cxxxiii. Zhou, R (2013). Study on BPR of Small to Medium Enterprise Based on E-commerce. Yanshan University, Qinhuangdao, China

cxxxiv. Zhu, W., Chew, I., \& Spangler, W. (2005). CEO transformational leadership and organizational outcomes: The mediating role of human-capital enhancing human resource management. The Leadership Quarterly. 16, 39-52

cxxxv. Z Zinatelli, N., Cragg, P., \& Cavaye, A.L. (1996), "End user computing sophistication and success in small firms," Journal of iInformation Systems, 5 (3), 172-81.

cxxxvi. Zygiaris. (2000). Business Process Re-engineering. MSc, BPR engineer. Johanesberg: BPR Hellas SA. 